\title{
Casa da Câmara e Cadeia: aplicação da Lei em Vila Boa de Goyas (1830-1890)
}

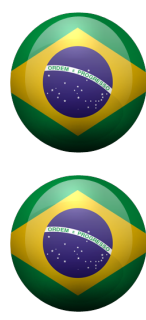

\section{Gercinair Silvério Gandara}

Docente da Universidade Estadual de Goiás. Pós-Doutora em História (UFG) Doutora em História Social pela UnB. Coordenadora do LHEMA/UEG, Líder do Grupo de Pesquisa Rios e Cidades na História do Brasil. Uruaçu [GO] Brasil. < gercinair.gandara@ueg.br>

\section{Paulo Henrique Ferreira da Silva}

Licenciado em História pela Universidade Estadual de Goiás, Auxiliar Judiciário na Comarca de Campinorte, Bolsista da Universidade Estadual de Goiás. Campinorte [GO] Brasil. < paulo215@outlook.com>

\section{Resumo}

As Casas da Câmara e Cadeia no período imperial foi umas das mais importantes construções novecentistas. Em "Vila Boa de Goyas" representou o poder da monarquia. 0 edifício se encontra em posição de destaque no Arraial, fixado no alto do Largo Chafariz de Cauda, com a finalidade de lembrar a população que ali existia a presença de representantes do Imperador. Entre 1830-1890, em Vila Boa de Goyas, as formas de punição adotadas pela justiça eram as penas de privação de liberdade que se davam de formas violentas e desequilibradas.

\section{Palavras-chave}

História de Goiás. Vila Boa. Cadeia. Punição.

\section{House of City Council and Jail House: application of the Law in Vila Boa de Goyas (1830-1890)}

\begin{abstract}
The House of City Council and the Jail House in the imperial period was one of the most important constructions in the 19th century in Brazil hinterland. In "Vila Boa de Goyas" (a city of the actual state of "Goiás", Brazil) it represented the power of the monarchy. The building is placed on a prominent position in the "Arraial" ("village"), fixed at the top of "Largo Chafariz de Cauda", in order to remind the population that there existed the presence of representatives of the Emperor. Between 1830 and 1890, in "Vila Boa de Goyas", the ways of punishment adopted by justice were the penalties of deprivation of liberty which were given in violent and unbalanced forms.
\end{abstract}

\section{Keywords}

History of "Goias" state. "Vila Boa" city. Chain. Punishment. 


\section{Introdução}

A história da "justiça" em Goiás se inicia com a fixação dos bandeirantes nas terras banhada pelo rio Vermelho. Por consequência da povoação da localidade adveio a necessidade da instalação de uma casa de leis. Isso se deu, mais especificamente, por volta de 1739 quando o Arraial de Santana recebeu o título de Capital da Província de Goiás, passando a se denominar Vila Boa de Goiás. Freitas (2014) nos diz que "nos turbulentos anos iniciais da capitania de Goiás, havia uma única vila e uma única comarca: a de Vila Boa de Goiás, fundada em 1739”.

Por quase dois séculos, foi sede do governo de uma vasta área continental que compreende cerca de um terço do território do brasileiro. Aos poucos, ali foram instaladas e passaram a funcionar instituições administrativas, militares, fazendárias, judiciarias e eclesiásticas. A justiça de primeira instancia era exercida pelos juízes ordinários, leigos e eleitos pela câmara municipal; a segunda instancia era alçada do ouvidor, com formação jurídica, nomeado e remunerado pelo Rei. (Freitas, 2014, p.113).

O território da comarca foi dividido pelo alvará de 18 de março de 1809, no qual previu a divisão judiciária da província de Goiás em Comarca do Sul e Comarca do Norte. A Comarca do Sul ficou sediada em Vila Boa e a Comarca do Norte, provisoriamente, no "arraial de Natividade" até a construção da Vila "São João das Duas Barras", que abrigou a segunda Comarca da Província. Além da extensão territorial que compreendia a província de Goiás outros fatores contribuíram para a dificuldade de se aplicar a lei na província. Parafraseando Nascimento (1997), segundo o relato de vários Presidentes de Província, aplicar a lei e fazer justiça em Goiás, eram tarefas difíceis porque aí havia um ambiente já viciado. Este autor explica que, [...]

[...] de um lado, o texto legal se identificava com a vontade e o querer dos grandes proprietários, e outro, escrivães, juízes e demais servidores grados da justiça estavam comprometidos com grandes senhores de terras (Nascimento, 1997, p.58).

A corrupção e os mandos que os proprietários de terras exerciam na oligarquia em Goiás retardava a efetivação das leis e garantia impunidade aos fazendeiros. Para decifrar tal dependência por parte dos servidores da justiça, destaca-se o fato de que estes eram indicados aos cargos pelos proprietários de terras. A falta de guarnição na Província de Goiás culminava, por consequência, no aumento da violência e na constante fuga de cativos. Nascimento (1997) nos explica que Goiás possuía um vasto território, uma população escassa e um contingente policial diminuído e despreparado. Estes fatos tornavam incapaz de se proteger as fronteiras, o que permitia o livre trânsito de todos aqueles - tantos cidadãos de bem, quanto vadios e malfeitores - que quisessem entrar ou sair do território. "As portas da província estavam abertas tanto a novos investimentos, quanto a roubos e assassinatos" (Nascimento, 1997, p.59).

A precariedade das instituições públicas se desencadeava na constante impunidade, além disso a falta de eficiência característica da justiça da província de Goiás impulsionava a proliferação de criminosos, Freitas (2014) nos salienta que "na justiça criminal, a situação era dramática. No interior distante, criminosos ficavam impunes, era quase impossível levá-los presos para a capital. Quando isso era feito, deviam ser escoltados pelos "soldados do quinto" - a mesma escolta que transportava o ouro de El Rei!” (Freitas, 2014, p.115).

Como se vê havia certa fragilidade na província de Goiás ligado ao fraco desenvolvimento econômico e fomentado pela má gestão dos recursos provinciais. Quanto a isso Palacin (1981) explica que $[\ldots]$

[...] nossos representantes à Câmara Alta (compreendendo Deputados e Senadores), embora eleitos, eram nomes impostos pelos ministérios e quase sempre filhos de outras províncias. A Assembleia Provincial e a Câmara dos Vereadores funcionavam de acordo com as ordens e interesse da Presidente da Província. Condicionado por uma série de fatores, como falta de meios de transporte e comunicação, grandes distâncias, descasos administrativos, desequilíbrio entre receita e despesa, ausência de um produto econômico básico, Goiás teve vida medíocre no transcorrer do século XIX (Palacin 1981, p.71). 
No entanto, após a instalação da Casa das Suplicações na cidade do Rio de Janeiro, o Imperador deu ordem para se iniciar a instalação dos Tribunais de Relações nas províncias do interior do Brasil. Goiás obteve um tribunal de segunda instancia meio século depois da promulgação da constituição de 1824.

A Casa da Câmara e Cadeia era umas das mais importantes construções de qualquer arraial do período imperial. Em Vila Boa de Goiás representou o poder da monarquia. Isso se verifica e pode ser retratada pela imponência de sua construção. 0 edifício se encontra em posição de destaque no Arraial. Mesmo nos dias de hoje, a sua construção representa respeito para a Cidade de Goiás.

Ao analisarmos a organização das construções do Arraial de Vila Boa foi possível perceber que não havia nenhum cuidado em deixar os edifícios públicos em destaque. Ali não dispuseram de linearidade ao construir qualquer edifício, seja a igreja ou o palácio provincial, fator característico de cidades coloniais portuguesas. Contudo, o que não era preocupação para a representação daqueles edifícios não se aplicou a construção da Casa da Câmara e Cadeia. Fixado no alto do Largo Chafariz de Cauda, o edifício se encontra bem localizado e em posição de destaque com a finalidade de lembrar a população que ali existia a presença de representantes do Imperador.

Não há datação exata sobre o ano e dia da fundação do edifício da Casa da Câmara e Cadeia de Vila Boa. Acredita-se que após a elevação do título da localidade de Arraial de Santana a Vila Boa de Goiás, no ano de 1739, com a consequente instalação do pelourinho, marco da emancipação municipal, Vila Boa tenha recebido o direito de julgar os criminosos de sua localidade, tendo a mesma fixado a Câmara. Supõe-se que ficando a mesma dotada do direito de julgar os criminosos suas autoridades tenham alugado uma casa provisória para os exercícios da Câmara e Cadeia.

Vale, ressaltar que nas pesquisas efetuadas no Arquivo Histórico de Goiás, instalado nas dependências do prédio da antiga Câmara e Cadeia encontramos um prospecto da primeira edificação deste estabelecimento de lei em Vila Boa de Goiás do ano de 1751. Este prospecto teve como seu criador Marcos Antônio Veiga. Este prospecto nos apresentou um prédio simples e funcional. Nele verifica-se que em sua primeira estrutura a edificação não contava com o andar superior. Sua fachada principal servia de acesso a Câmara e na fachada da lateral à direita ficava a entrada para a Cadeia. A parte interna dessa edificação é desconhecida, embora exista algumas reproduções de como seria o formato interno deste estabelecimento, mas não há documentação que a comprove.

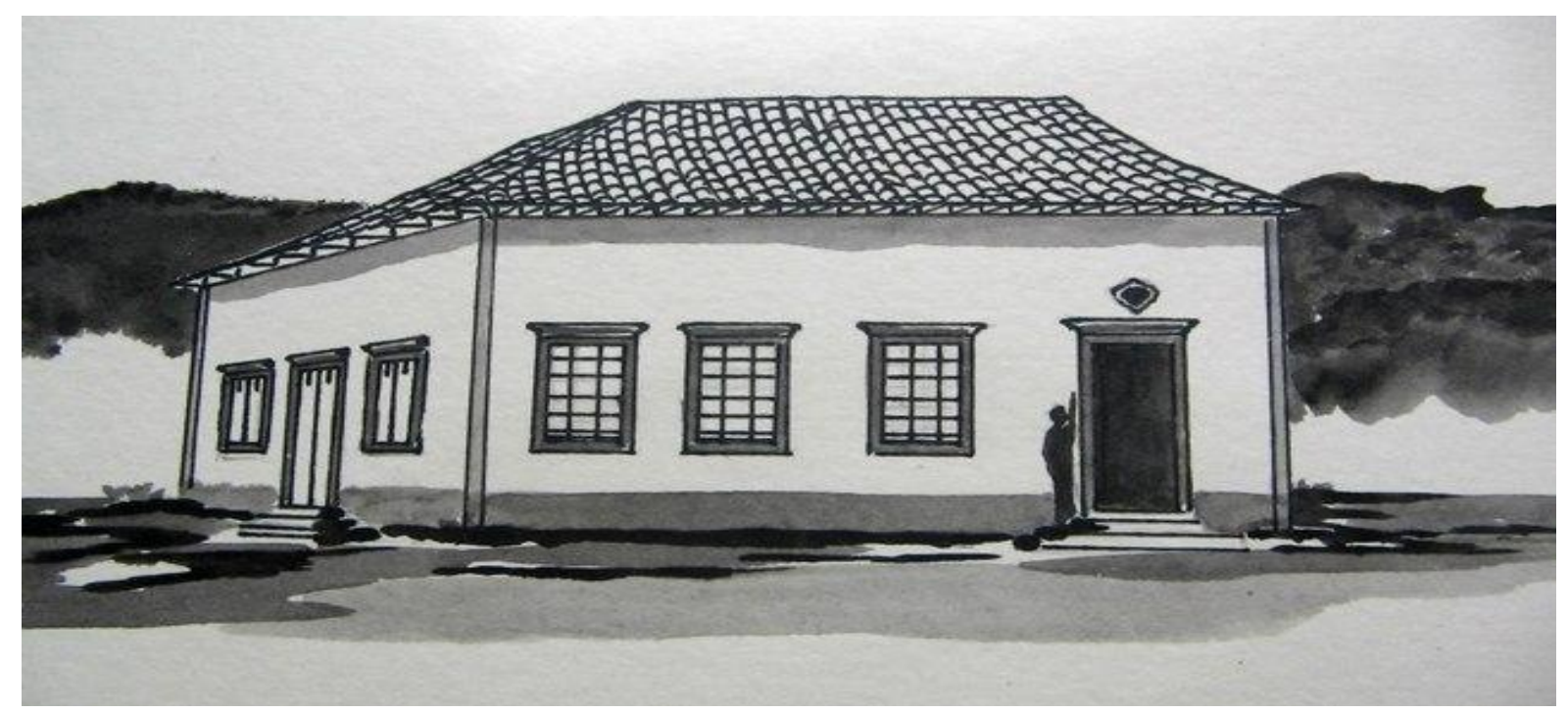

Figura 1. Prospecto do primeiro edifício da Câmara e Cadeia em Vila Boa de Goiás. Fonte: Museu das Bandeiras, Arquivo Histórico da Cidade de Goiás. Marcos Antônio Veiga, prospecto da Casa da Câmara e Cadeia de 1751.

A arquitetura atual da Casa de Câmara e Cadeia foi estabelecida logo após a instalação da forca, no ano de 1760 . Sua construção iniciou no ano de 1761 e foi finalizado em 1766 no reinado de Dom José I e, como governador da Província de Goiás, o Capitão General João Manoel de Mello (1759-1770). 
Em suas novas instalações o edifício da Casa de Câmara e Cadeia ganhou uma fachada imponente composta por quatorze janelas sendo que sete delas se dispõem na fachada do plano baixo e outras sete compõem o plano alto. Três das janelas da faixada do plano baixo são originais do primeiro edifício. É notória a diferença dessas com as demais. 0 edifício dividido em dois planos sendo que no plano baixo ou térreo ficava instalada a Cadeia. Compunha este plano duas casas forte sendo uma a direita e outra à esquerda. Entre as duas existia/existe uma sala de recepção onde ficava o acesso a Câmara por meio de uma escada em madeiras e uma sela feminina. Logo atrás da sala recepção há um corredor de acesso a casa do carcereiro ${ }^{1}$ e a prisão privada. No plano alto, há uma sala de entrada onde à direita se dá acesso a sala de espera e à Câmara. $\mathrm{Na}$ parte esquerda fica a sala de audiências, local em que se fazia os julgamentos, e a sala livre, local em que o júri se reunia para deliberar. Um pouco atrás está o oratório, a varanda e uma sala que servia de prisão para as mulheres. A imagem que se segue oportuniza compreender a fachada da Casa da Câmara e Cadeia de Vila Boa no século XIX.

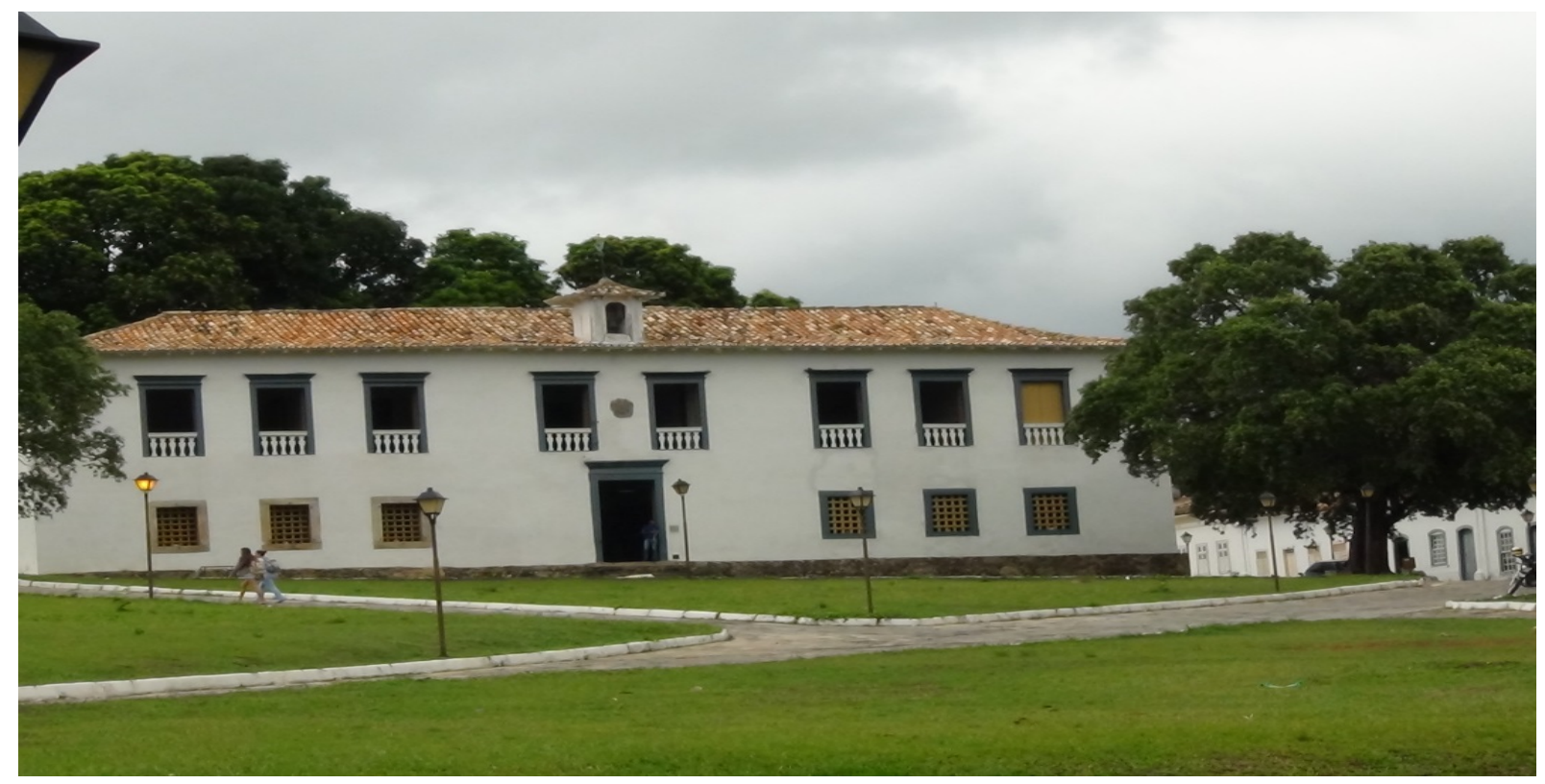

Figura 2. Foto da Casa da Câmara e Cadeia de Vila Boa de Goiás. Fonte: Acervo Particular do Autor.

A Casa Forte é dotada de paredes largas revestida por madeira de aroeira e nas janelas grades de ferro. Este era o espaço que se mantinha presos os criminosos. A única forma de acesso concedida aos presos era uma escada que servia para conduzi-los à sala de audiências via a um alçapão. Há relatos documentais de que a sela era fria e insalubre, repleta de fezes e ratos e o mau cheiro era visível. Esta condição da Cadeia se verifica nos relatos oficiais.

Juiz de Direito da Comarca Especial da Capital de Goyaz, 14 de novembro de 1890. Ao cidadão Presidente da Intendência principal da Capital para providencia afim de que seja transferido os ofícios para a sessões do jury. Governo do estado de Goyaz, 20 de novembro de 1890.Estando designado o dia 15 de Dezembro para abrir-se a 11 a sessão do judiciaria do termo desta Capital e não oferecendo o antigo paço da Intendência Municipal, situada no pavimento superior da Cadeia desta Capital, o asseio necessário para nele funcionar o jury, as crescentes sinais que a sala secreta do conselho do jurados e colocada sobre o lugar reservado para decisões, tornando a dita sala infeccionada, $e$ tendo em diversas sessões reclamações por parte dos jurados, venho pedir-vos autorização para que na informada sessão do jury possa funcionar no oficio excepcional em que atualmente o conselho da intendência dá suas sessões. Saúde e fraternidade. Sr. Dr. Rodoalpho Gustavo de Paisão. Governador deste Estado de Goyaz. Alfredo Augusto Conrado (Oficio do ano de 1890 direcionado ao governador da província de Goiás. (Acervo Digital do Museu das Bandeiras).

${ }^{1}$ Cômodo onde descansavam os agentes carcereiros. 
O quadro de funcionários da Cadeia era composto por um Inspetor geral, cargo dado ao chefe de polícia da Província que ficava encarregado de chefiar todas as atividades existentes na mesma. Era, também, responsável pela administração e segurança do estabelecimento. 0 carcereiro era o agente responsável por executar todos as atividades internas da Cadeia tais como, a manutenção da cadeia e a vigilância dos presos. Além do carcereiro havia a figura do ajudante de carcereiro que ficava responsável para auxiliar o carcereiro em suas atividades e assumir suas funções quando estivesse ausente. Um fato curioso encontrado em nossas pesquisas efetuadas nos registros oficiais da Cadeia de Vila Boa foi que o ajudante de carcereiro não possuía vínculo com o Estado, pois o mesmo era contratado pelo carcereiro ao qual era responsável por arcar com os seus vencimentos. Assim sendo, o mesmo era destituído do cargo automaticamente caso o carcereiro deixasse de prestar serviços à província.

A partir de uma análise dos registros oficiais expedidos pela justiça em 1856, constatamos que havia um grave problema no que se refere a figura do carcereiro. Segundo os relatos não havia quem queria servir ao trabalho em razão do risco de morte que corria quem assumisse a função. Além disso, os ganhos não eram compatíveis com as atividades exercidas. Era muita responsabilidade dada ao carcereiro, pois se caso houvesse fugas de presos ele seria responsabilizado e processado por incompetência ou por conivência com o ato criminoso. Isso fazia a profissão pouco atrativa aos olhos da população.

Constatamos a existência de outros estabelecimentos prisionais na Província de Goyaz, nas quais os carcereiros possuíam as mesmas atribuições. Por meio do mapa oficial dos carcereiros da Província de Goyaz evidenciamos as localidades que possuíam Casa de Câmara e Cadeia. No mapa oficial, conforme descrito no quadro abaixo, se identifica os nomes dos carcereiros e as datas de suas nomeações, bem como, quais eram seus proventos.

Quadro 1. Transcrição do Mappa Oficial dos carcereiros da Província de Goyaz.

\begin{tabular}{|c|c|c|c|c|}
\hline Lugares & Nomes & Exercício & Gratificação & Observações \\
\hline Capital & João Corrêa de Brito & Interino & $240 \$ 000$ & Nomeado á 19 de abril de 1872 \\
\hline Jaraguá & Antonio dos Santos Vilarinho & Effectivo & $60 \$ 000$ & Idem á 16 de julho de 1866 \\
\hline Meia Ponte & Manoel Cardozo de Almeida & Idem & $80 \$ 000$ & Idem á 23 de agosto de 1871 \\
\hline Corumbá & Clemente Pereira Gabino & Idem & $60 \$ 000$ & Idem á 25 de fevereiro de 1862 \\
\hline Santa Cruz & João José da Rocha & Idem & $80 \$ 000$ & Idem á 27 de agosto de 1866 \\
\hline Bomfim & Vago & - & - & - \\
\hline Santa Luzia & Balbino Xavier Borges & Idem & $60 \$ 000$ & Idem á 4 de agosto de 1861 \\
\hline Catalão & Zeferino Lopes Zedes & Idem & $120 \$ 000$ & Idem á 12 de março de 1862 \\
\hline Pilar & Joaquim Soares Baptista & Idem & $60 \$ 000$ & Idem á 23 de maio de 1854 \\
\hline Trahiras & Jacintho de Lemos & Idem & $60 \$ 000$ & Idem á 7 de dezembro de 1846 \\
\hline Cavalcante & Antonio Joaquim de S. Anna & Idem & $80 \$ 000$ & Idem á 30 de julho de 1845 \\
\hline Palma & Francisco de Almeida Campos & Idem & $80 \$ 000$ & Idem á 2 de janeiro de 1851 \\
\hline Natividade & Manoel Luiz Mendes Vieira & Idem & $60 \$ 000$ & Idem á 8 de abril de 1861 \\
\hline Conceição & João da Costa Rego & Idem & $80 \$ 000$ & Idem á 30 de junho de 1870 \\
\hline Arraias & Domingos de Araujo Barcellos & Idem & $60 \$ 000$ & Idem á 6 de Novembro de 1863 \\
\hline Porto Imperial & Beraldo José de Almeida & Idem & $60 \$ 000$ & Idem á 9 de março de 1871 \\
\hline Boa Vista & Domingos Cardozo de Lima & Idem & $60 \$ 000$ & Idem á 9 de janeiro de 1869 \\
\hline
\end{tabular}

Fonte: Secretaria da Polícia em Goyaz 18 de maio de 1872. Secretário: Francelino Fenelon de Loyola. (Acervo Digital do Museu das Bandeiras).

Em toda Província de Goyaz o formato das dependências não fugia a regra e, em sua maioria, as Casas da Câmara e Cadeia eram consideradas obsoletas e insalubres. Além disso, a fragilidade 
nas instalações das Cadeias era bem evidentes, pois há uma gama de relatórios oficiais que comprovam a decadência que se encontravam por toda a Província. Essa fragilidade se verifica e constata no trecho do Relatório Oficial do Presidente da Província de Goyaz, Dr. Antônio Augusto Pereira da Cunha, no ano de 1856: [...]

[...] Há na Província 12 cadêas, a saber: a da capital, Meia ponte, Corumbá, Bom fim, Santa Luzia, Santa Cruz, Catalão, Pilar, Trahiras, Cavalcante Natividade e Porto Imperial. Nenhuma dellas tem accomodações e segurança necessarias, e antes se acham quasi todas em pessimo estado, a d'hi vem que não obstante ser preciso traspor grandissimas distancias, frequentemente são remettidos para a cadêa da capital, com difficuldade e perigo, presos que deverião ser conservados nas cadêas dos differentes termos da província, e que não poucas vezes tem evadido durante a viagem. Alem das 12 cadêas há ainda nas Villas de Jaraguá, São José, Formosa, Flores, Arraias, e Boavista pequenas casas que se denominão de prisão, e como taes servem, por decisão, apesar de não terem as condições dispensáveis para isso. [...] (Relatório oficial do Ex. Presidente da Província de Goyaz ano de 1856, o Exmo. Dr. Antônio Augusto Pereira da Cunha. Acervo Digital do Museu das Bandeiras).

Percebe-se, a partir da citação supramencionada, que não havia cadeia segura na província de Goyaz, sendo as dependências das cadeias precárias e de fácil evasão. Além das frágeis Cadeias, existiam as casas de prisão que eram casas residenciais improvisadas para servirem como Cadeias. As mesmas não conseguiam manter presos por muito tempo os seus cativos, pois não possuíam segurança alguma para servirem de prisão. Das casas que serviam de cadeias pode-se evidenciar no Relatório Oficial de 1856 em que relata o estado da Casa de prisão da Vila de Jaraguá.

Por falta de cadêa serve nesta Villa de prisão uma casa allugada para este fim pela câmara municipal. Não tem a menor segurança e nem as accommodações precisas. Ainda a pouco tempo della evadio-se o único preso que ahi tinha sido provisoriamente recolhido; entretanto, pela posição em que se acha, em relação esta capital, e pela circunstância do tempo, entendo que não reclama o seu estado, aliás pouco linsongeiro, a mesma attenção que e devida ao das outras cadêas da província. (Relatório oficial do Ex. Presidente da Província de Goyaz ano de 1856, o Exmo. Dr. Antônio Augusto Pereira da Cunha, referente ao estado de conservação da casa de prisão de Jaraguá. Acervo Digital do Museu Das Bandeiras).

A fraqueza dos cofres da fazenda provincial devido à falta de dinheiro referente ao processo de transição pelo qual a província passou durante a queda da produção aurífera desencadeou uma onda de sucateamento do aparato do Estado, somados ao péssimo desempenho das cadeias na Província. A justiça não era independente do executivo, pois o judiciário se subordinava a fazenda provincial para solicitar recursos no intuito de atender as menores ações referente a evasão de presos que eram constantes. Destarte, a fuga dos presos era um bom recurso para evitar suas desgraças, uma vez que, a cadeia era repudiante e as sentenças do judiciário do império pesadas.

As fugas quase sempre eram bem-sucedidas, devido à falta de estrutura das cadeias. As técnicas de fugas eram bem arquitetadas e os presos ao fazer tal ato recebiam ajuda de terceiros. Os arrombamentos eram comuns, há relatos de que as grades das janelas da casa forte eram forçadas ao extremo pelos estranhos que por fora facilitava a fuga dos criminosos. Há nos documentos do Acervo digital do Museu da Bandeiras registros oficiais que narram a participação de um carcereiro na fuga de um dos presos, tal registro refere-se a casa de prisão de Boavista no ano de 1872. O Relatório apresentado á Assembleia Legislativa Provincial de Goyaz pelo Exm. Sr. Dr. Antero Cicero de Assis, Presidente da Província, em 1o de junho de 1872 nos apresenta o relato de uma dessas fugas.

No dia 18, porém, foi arrombada a prisão da casa forte onde estava Capanga, que evadio-se, reconhecendo-se ter sido praticado o arrombamento pela parte de fóra. $O$ carcereiro que dormia no sobrado, logo que presentio rumor, correu á casa forte e pode evitar a fuga de um outro criminoso que tambem na dita prisão se achava. Nesse dia não havia guarda na cadêa porque quatro das praças do destacamento se achavão na villa de Pouso-Alto em deligencia com o respectivo delegado de polícia, e a unica existente estava doente em consequência dos ferimentos que recebera no acto de ser

(C) Labor \& Engenho, Campinas [SP] Brasil, v.12, n.2, p.240-252, abr./jun. 2018. 
preso Antonio Capanga. $O$ dito delegado tomou conhecimento de todos esses factos $e$ instaurou os devidos processos (Acervo Digital do Museu Das Bandeiras).

Apesar de todas as dificuldades que enfrentava o arraial de Vila Boa de Goyaz a sua Cadeia era a que mais próximo chegava de uma cadeia ideal em toda a Província. A mesma, segundo a perspectiva da época, em seus anos iniciais atendia as necessidades da comunidade sendo referência para as demais construções de Casas da Câmara e Cadeia na Província. Além da cadeia da capital, outra que melhor atendia aos requisitos de uma prisão era a cadeia de Trahiras, reconhecida pela província como uma das mais seguras. A cadeia de Trahiras e a da capital serviam de destino a presos de outros arraiais da província de Goyaz e demais regiões do Império do Brasil.

\section{Os crimes previstos e os cometidos na Província de Goyas}

Os crimes previstos por lei no Império eram variados. Havia os crimes particulares como Furto, Homicídio e Estupro e os crimes públicos, tais como, Fuga de Presos e Crimes contra o Chefe do Governo. Contudo, durante os anos de 1848 a 1856, na Província de Goyaz, dos crimes cometidos se destacam os Crimes de Tirada ou Fuga de Presos, Ferimentos e "Offensas Physicas", Homicídio, Furto e Roubo. Nos dados oficiais informados em Estatística dos crimes cometidos e julgados no nonênio de 1848 a 1856, apresentada pelo Ministro Francisco Diogo Pereira de Vasconcelos se pode verificar o leque de crimes cometidos na Provincia de Goyás. Vide tabela transcrita da Estatística dos crimes cometidos e julgados no nonênio de 1848 a 1856 apresentada no Relatório de 15/05/1858.

Quadro 2. Estatística dos crimes cometidos e julgados no nonênio de 1848 a 1856.

\begin{tabular}{|c|c|}
\hline Crimes Públicos & $\begin{array}{l}\text { Quantidade de } \\
\text { casos registrados }\end{array}$ \\
\hline Do Artigo 73 do Código Penal & 0 \\
\hline Contra a Constituição e forma do Governo & 0 \\
\hline Contra o livre exercício dos Poderes políticos & 0 \\
\hline Contra o livre gozo e exercício dos direitos políticos dos cidadãos brasileiros & 0 \\
\hline Contra o Chefe do Governo & 0 \\
\hline Conspiração & 0 \\
\hline Rebelião & - \\
\hline Resistência & 2 \\
\hline Tira ou fuga de presos & 5 \\
\hline Perjúrio & 1 \\
\hline Total & 8 \\
\hline Crimes Privativos & $\begin{array}{l}\text { Quantidade de } \\
\text { casos registrados }\end{array}$ \\
\hline Contra a liberdade individual & 2 \\
\hline Homicídio & 106 \\
\hline Infanticídio & 0 \\
\hline Aborto & 0 \\
\hline Ferimentos e offensas physicas & 63 \\
\hline Ameaças & 4 \\
\hline Estupro & 0 \\
\hline Rapto & 1 \\
\hline
\end{tabular}




\begin{tabular}{|l|c|}
\hline Calumnia e injuria & 2 \\
\hline Poligamia & 0 \\
\hline Adultério & 0 \\
\hline Furto & 12 \\
\hline Bancarrota, estelionato, e outros abusos contra a propriedade & 1 \\
\hline Damno & 3 \\
\hline Roubo & 11 \\
\hline Total & 205 \\
\hline Crimes Policiais & $\begin{array}{c}\text { Quantidade de } \\
\text { casos registrados }\end{array}$ \\
\hline Offensas á Religião, moral e bons costumes & 0 \\
\hline Ajuntamentos ilícitos & 1 \\
\hline Vadiação & 0 \\
\hline Armas defesas & 16 \\
\hline Fabrico e uso de instrumentos para roubar & 0 \\
\hline Total & 17 \\
\hline
\end{tabular}

Fonte: Relatório apresentado a 15/05/1858 (pp. 14-18) pelo Ministro Francisco Diogo Pereira de Vasconcelos. Ministério da Justiça: Relatórios, pct. 483, Fundo Brasil Império (Museu das Bandeiras).

A partir dos dados informados acima, pode-se observar que os crimes cometidos em Vila Boa eram em sua grande maioria relacionados aos crimes privados. Uma pequena parcela dos delitos registrados possui relações com os crimes públicos, mas mesmo sendo desta natureza apresentam ligação com os crimes privados, como por exemplo a fuga de presos. No entanto, pode ter ocorrido certa negligência por parte da justiça goiana da época em processar e punir os delinquentes que podem/poderiam ter cometido crimes que lese o Estado. Por outro lado, ficou evidente que o crime contra a pessoa como o homicídio, o furto e o roubo foram fortemente representados como delito. A frequência desses delitos pode ser justificada pela carência financeira e a ganância por rendimentos, ou coisas fúteis do dia a dia. As razões dos crimes são variadas tornando muito complexa a justificativa para o acontecimento dos crimes. Curiosamente, nos convencemos, por meio de alguns documentos pueris do arquivo da Cidade de Goiás, de que por mais que houvesse uma elevada quantidade de homicídios e roubos os criminosos eram misteriosamente absolvidos pelo tribunal do júri. 0 comportamento dos jurados nos levou a refletir sobre o que levava o júri a este comportamento. Nascimento (1997) enfatiza que para os presidentes da Província, [...]

[...] a impunidade era exatamente o grande fator que em Goiás fosse aumentado cada vez mais o número de criminosos, vadios e vagabundos proveniente das províncias circunvizinhas, os quais estavam a fugir da ação da justiça. Igualmente contribuía para tanto, o fraco desempenho dos membros do júri, que, por insegurança, ou medo e ou desconhecimento das leis, votavam pela absolvição dos réus (Nascimento, 1997, p.61).

Ao averiguar as afirmações de Nascimento (1997) entende-se que não havia preparo por parte do júri ao deliberar sobre os crimes. A justificativa dada na referência acima pode estar ligada a insegurança, ou seja, por medo de condenar o réu e sofrer retaliações o júri absolvia o criminoso, e/ou por ignorância e não conhecer as leis, cometiam tal injustiça. Pela Estatística dos "Crimes Commettidos e Julgados no Nonennio de 1848 a 1856" apresentada em Relatório de 15/05/1858 pode-se confirmar os efeitos das decisões dos jurados. Segue alguns dados da referida estatística.

Analisando os dados apresentados no Quadro 3 comungamos com Nascimento (1997), pois percebemos que a impunidade prevalecia frente aos julgamentos. Isso fazia com que na província de Goiás prevalecesse a impunidade. Fator este que pode ter servido de incentivo para atrair novos malfeitores de outras régios às terras goianas. 
Quadro 3. Estatística dos "Crimes Commettidos e Julgados no Nonennio de 1848 a $1856 "$.

\begin{tabular}{|l|l|l|}
\hline Período de julgamento & Atuação do Júri / Absolvições & \\
\hline Data dos crimes: 1848-1856 & Por Decisão do Júri: 129 & \\
\hline Data dos julgamentos: 1848-1856 & Por prescrição: 0 & \\
\hline \multirow{2}{*}{ Número de processos: 198 } & Por perempção: 3 & \multirow{2}{*}{ 66 condenados } \\
\cline { 2 - 3 } & Total: 132 & \\
\hline
\end{tabular}

Fonte: Relatório apresentado a 15/05/1858 (pp. 14-18) pelo Ministro Francisco Diogo Pereira de Vasconcelos. Ministério da Justiça: Relatórios, pct. 483, Fundo Brasil Império, (Museu das Bandeiras).

A maioria dos réus eram do gênero masculino, solteiros, negros ou índios, de 21 a 41 anos. Estas estatísticas estão presentes em diversos relatórios oficiais preservados no arquivo instalado no edifício da Cadeia de Vila Boa. Para se compreender o perfil dos réus é preciso observar as condições sociais a qual este grupo de pessoas estavam inseridos. Em nossas pesquisas ficou evidente a falta de presos ricos. Nascimento (1997), atribui a falta de processos e registro de presos ricos, ao fato de que os cargos do judiciário goiano da época serem compostos por indicações feitas por "homens de bem". "Estes "homens de bem" eram os fazendeiros e mineiros, pessoas com grande poder aquisitivo. Dessa forma era pouco provável que a justiça indicada por estes homens iria processá-los e muito menos condená-los" (Nascimento, 1997, p. 61).

Crê-se que os crimes que envolviam pessoas que possuíam grande poder aquisitivo não tramitavam em Vila Boa, e/ou tais ocorrências eram passíveis de recurso a outros tribunais do império devido ao poder aquisitivo dos prováveis envolvidos. Em verdade, estes processos eram remetidos a cidade do Rio de Janeiro capital do Império e lá recebiam apreciação da segunda corte e do poder moderador. Já os crimes que envolviam pessoas pobres quase não se pediam o recurso. Isso ocorria devido o valor para se remeter dos autos ao Rio de Janeiro que se tornavam onerosos aos pobres tal direito. Havia exceções, casos que os proprietários de escravos pediam recurso para os seus negros, temendo perdê-los, ou o apelo da Irmandade da Misericórdia, que às vezes fazia um apelo pela comutação das penas, mas na maioria das vezes eram infrutíferas. Além deste perfil de condenados, havia as presas mulheres, de idades variadas, mas em quantidade menor. Em sua maioria, as mulheres presas eram escravas que cometiam desde os delitos simples até o homicídio. Dentre tais mulheres destaca-se a escrava Rosa Peregrina que por haverem assassinado a sua senhora, mulher do Brigadeiro Jacintho Pinto Teixeira, a mesma foi condenada a "pena última" (ou seja, pena de morte).

A partir da análise sobre o perfil dos condenados percebemos que os menos afortunados recebiam o rigor da lei e os seus excessos, já os ricos não haviam o que se condenar, pois os mesmos possuíam grandes influência sobre a justiça existente. Crê-se que o corpo de jurados não ousaria condenar um homem rico temendo, talvez, receber retaliações.

\section{As Punições Aplicadas na Cadeia de Vila Boa}

No início da produção do ouro em Goiás, a administração da região das minas de Goiás era subordinada a capitania de São Paulo, sendo que toda a estrutura administrativa era paulista. Como autoridade da localidade se destacava a figura do superintendente das Minas ou intendente mor. Quem primeiro assumiu este cargo foi Bartolomeu Bueno da Silva, o Anhanguera. O Intendente Mor era a figura responsável pela arrecadação do quinto ${ }^{2}$. No caso de Bartolomeu Bueno da Silva além de ser o responsável pela arrecadação e administração do Arraial de Santana era o chefe da Guarda Mor. Posteriormente, o mesmo assumiu os principais cargos de Vila Boa. Sendo assim acredita-se que, devido a distância de São Paulo e a falta de comunicação há sinais de que a justiça era improvisada, pois o evidente acumulo de poder de Bartolomeu fez do mesmo o maior representante da Coroa em terras goianas daquele tempo.

Não obstante, é difícil afirmar sobre os métodos punitivos antes da fundação da Cadeia de Vila Boa de Goiás, pois não há registros que comprove as formas adotadas por Bartolomeu Bueno da Silva

2Imposto cobrado pela metrópole portuguesa 
para punir os infratores que confrontassem os interesses da Coroa. Todavia Vila Boa, após a fundação da Casa da Câmara e Cadeia, experimentou dos feitos da justiça de primeira instância e para as delinquências havia a punição severa. Dentre as punições aplicadas se destacam como principais, a pena de morte, a galés, a prisão com trabalho e prisão simples, o banimento, degredo e/ou desterro, multa, suspensão do emprego, inabilidade do emprego, perda do emprego e açoutes. Estas penas, em sua maioria, eram determinadas pelo tribunal do júri ou por decisão do juiz de fora ou juiz de direito.

O condenado a galés era o réu condenado ao uso de calceta nos pés, que se trata de uma espécie de corrente que se prendia aos pés e ao trabalho forçado a disposição da Província. 0 trabalho deste condenado era direcionado pelo presidente da Província ou Intendente. Em verdade, identificavam uma necessidade de uma construção pública e o condenado a galés deveria trabalhar, sempre vigiado por um guarda, sem receber nenhuma remuneração.

Na condenação à prisão com trabalho, os condenados eram confinados e obrigados a trabalhar. Geralmente o trabalho destes condenados era exercido dentro das dependências da própria cadeia, no caso de Vila Boa os condenados a esta pena trabalhavam em uma oficina de sapatos que ficava na parte de traz da cadeia. Os presos confeccionavam sandálias baratas e de pouca qualidade, pois a matéria prima a qual os mesmos tinham acesso era de baixa qualidade. A Intenção desta oficina era a de reinserir os presos ao âmbito do trabalho e garantir o sustento mínimo ao condenado. Acreditava-se que o trabalho edificava a alma e quando exercido ocupava os prisioneiros fazendo com que os mesmos esquecessem por um momento a criminalidade. Os frequentadores da oficina eram remunerados pelo trabalho exercido. Uma parte de sua remuneração era para garantia de sua comida e a outra parte era paga ao condenado, isto é, quando requerido formalmente pelo preso. Por meio da reportagem veiculada no Jornal Goyaz do ano de 1885 podemos compreender o que se pensava sobre a temática naquela época.

[...] Não há hoje nação culta que não tenha eliminado do seu código penal, ou não esteja cuidando de eliminar d'elle a pena de prisão sem trabalho, por considerá-la depravadora; alêm de desacostumar do trabalho todos os condemnados, que, antes da perpetração do delicto, estavam a elle habituados; ou alêm de não acostumar ao trabalho todos os vadios, que na ociosidade encontraram o incentivo ao crime, a pena de prisão simples á ainda corruptora porque a ociosidade forçada, no recinto de uma prisão, exaspera, dentro de maior ou periodo, o sentenciado; entrando para expiar muitas vezes um delicto relativamente pequeno, sae o condemnado, findo o seu tempo da prisão, indolente, desbriado e, o que ainda é peior, em estado de rebeldia latente contra essa sociedade, a que foi restituido, de que vai novamente fazer parte, a que entretanto vota agora odio concentrado, e de que se tornou membro mais perigoso depois da expiação do que se não houvesse sido punido nunca. [...] (Jornal "Goyaz", 26/12/1885, ano I, no 14, p. 1, Hemeroteca Digital Brasileira, e acervo digital do Museu das Bandeiras, transcrito por Milena Bastos Tavares).

Ao fazer a leitura desse texto do Jornal Goyaz, percebe-se, em parte, qual era a visão da sociedade daquela época acerca do trabalho nas prisões. Nota-se que havia grandes argumentos a favor destas técnicas de punição. Mas, também apresenta um certo sentimento de repúdio a pena simples que se trata da punição do confinamento do réu sem a prática do trabalho. A justificativa para reprovação da pena simples era a de que o condenado nada iria fazer dentro da cadeia e isto iria torná-lo ocioso fazendo da cadeia um atrativo aos delinquentes e malfeitores.

Além das mencionadas tinha aquela conhecida como pena última, ou seja, a pena de morte. Esta era a pena máxima praticada no Brasil do século XIX. Os condenados a pena última eram criminosos que cometiam homicídio, estupro e outros crimes de grande proporção e que causava comoção na sociedade. Vila Boa de Goyas não fugia a regra, pois ao pesquisar sobre esta punição encontramos a história narrada por Cora Coralina em seu livro intitulado "Casa Velha da Ponte" em que descreve a aplicação característica da pena última. A história detalhadamente contada por Cora Coralina, ocorreu entre os anos de 1839 a 1841. Ela se refere à condenação dada ao assassinato de D. Antônio, pessoa com grande poder aquisitivo e bem reconhecido na sociedade. 0 mandante do crime foi Luiz Gonzaga de Camargo Filho, pessoa que também possuía prestigio na sociedade da época. A morte se deu em confronto armado com a guarda provincial. 0 condenado à 
morte que aparece na sua narrativa era Miguel Carrilho de nacionalidade boliviana. 0 crime causou grande comoção na cidade, pois se tratava da morte de pessoas de prestigio social, mas o condenado não teve escolha a não ser se entregar.

A autora narra o caso cheio de detalhes, de tal forma que quando lido parece levar o leitor à cena de ocorrência do crime, contudo ela discorre se valendo da memória, o que leva a crer que pode ter faltado com alguma informação ou acrescentado outras. No entanto, provando que o caso de fato ocorreu, apresentamos o ofício cujo remetente é o Ministro da Justiça do Império Brasileiro que se direciona ao Presidente da Província de Goiás solicitando informações acerca do processo de Miguel Carrilho. Nele destaca a forma como a pena era aplicada, demostrando sempre que a justiça da monarquia estava sempre presente para defender os seus interesses. A cena do enforcamento causava horror nas pessoas, pois a partir daquele momento reafirmavam o seu temor a justiça.

[...] O carrasco passava o condenado para a frente do tablado, jogava com destreza a corda no gancho avançado uma vara para frente, prendia a roldana na vigota, postava-se atrás do paciente. Do palanque da justiça, o oficial meirinho lia pela última vez o libelo condenatório. Finda a leitura, o carrasco unia os dois braços e dava o impulso fatal com as duas mãos espalmadas nas omoplatas do condenado e o joelho contra a base da coluna vertebral. O condenado era projetado fora do tablado, esperneando e sacudindo os braços. A corda distendia-se com o peso e o esforço da vítima; aí o carrasco fazia seu salto espetacular de felino e caia de gancho sobre os ombros do paciente, sacudia, balançava. O occipício se deslocava, a cabeça pendia sobre o peito, a língua vinha de fora com uma bica de sangue. $O$ carrasco saltava para o chão ou deslizava pelo morto, subia como um gato $e$ corria a corda pela carretilha, baixava o corpo que os irmãos da Misericórdia recebiam. $O$ físico ou medico, se havia, verificava o óbito, o que consistia durante muitos anos em passar um espelho pela boca do defunto. [...] (Coralina, 2006, p.85).

Em verdade, a história de caso contada em "Casa Velha da Ponte" aconteceu de fato e, pode ser provada por meio de documentações existentes no museu das Bandeiras.

Illmo e Exmo. Snr. Não se tendo recebido nesta Secretaria d'Estado dos Negocios da Justiça, o Officio dessa Prezidencia, de que trata o requerimento incluso de João Luis Xavier Brandão e Pedro Luis Xavier Brandão, acerca do réo Miguel Carrilho, natural de Bolivia, que fora condemnado á pena última por haver assassinado o Pai dos Supplicantes; Ordena o Regente em Nome do Imperador, que V. Ex $x^{a}$, com a possivel brevidade, enforme circunstanciadamente sobre este objecto. Deos Guarde a V. Ex $x^{a}$. Palacio do Rio de Janeiro em 28 de Março de 1840. Francisco Ramiro de Assis Coelho. Snr. Prezidente da Província de Goyas. (Avisos e Ofícios dirigidos à Presidência, pct. 01, Ano 1840, Cx. 30. Doc. Avulsa - Museu das Bandeiras e Arquivo Histórico Estadual de Goiás).

A justiça Goiana era fraca, falha e lenta, mas o que pudemos constatar é que quanto sentenciado o réu recebia penas excessivas. Além das penas, a privação na cadeia era constante, a insalubridade das salas forte e a falta de alimentação era os grandes desafios dos presos, um desafio a vida. Os relatos da falta de comida aos/para os presos eram constantes. Encontramos inúmeros ofícios do Inspetor da Cadeia ao presidente da Província e ao chefe da fazenda real, suplicando por alimento aos presos pobres. A exemplo deste documento abaixo dos anos de 1824 a 1828 em que fica evidente que havia dificuldades por parte da Câmara e administração da Cadeia em manter o sustento dos presos.

Abril 30. Partecipando as providencias dadas afim de ser socorridos os prezos das Cadeas desta Capital do necessario alimento. № 17.Illmo e Exmo. Snr. - Representando-me com instancia os prezos da Cadea desta Cidade a fome que sofrião, informado eu de haver dias em que elles passavão sem comer, ouvi a Camara a tal respeito, que certificando ser assim verdade, mostrava a impossibilidade de serem soccoridos pelo Conselho por falta de meios que este tinha: rezolvi-me a abrir a subscripção voluntaria incluza em $n^{\circ} 1^{\circ}$ e e por ella se deixa conhecer o estado decadente desta Cidade, chegando apenas a sua totalidade á quantia de $9 \$ 515$ réis mensaes; quantia que julguei não bastante, ao mesmo tempo que a

(C) Labor \& Engenho, Campinas [SP] Brasil, v.12, n.2, p.240-252, abr./jun. 2018. 
Camara não tinha votado ainda couza alguma; dirigilhe o Officio copia $n^{-} 2$, e pela sua resposta copia no3 consignou 4:000 réis mensaes, receoza de lhe ser estranhada esta despeza, me encarrega de obter de Sua Magestade Imperial a approvação sobre este pequeno rendimento [...] (Registro dos ofícios, representações e informes, 1824/1828, fl. 70v-72 pct. Tribunal da Relação, Correspondências A Ministério da Justiça Arquivo Real Fazenda, Museu das Bandeiras, Transcrição: Milena Bastos Tavares, historiadora e arquivista).

Nota-se, pela leitura do documento que os que mais sofriam eram aos condenados a pena simples e o condenado a Galés. Estes não recebiam pelo seu trabalho, desta forma seu sustento era exclusivamente aquele oferecido pela Cadeia que naquele momento não dispunha de recursos para manter a alimentação de tais pessoas, já aqueles não eram destinados ao trabalho e por esta razão não tinham recursos. Mas, encontramos documentos que comprovam o auxílio do Hospital de Caridade de Vila Boa, o qual foi extremamente importante para o sustento dos presos pobres que abrigava a cadeia de Vila Boa. Sobre a direção da irmandade de Santana atendia diariamente, por ordem do presidente da Província de Goiás, o Hospital de Caridade de São Pedro de Alcântara, os presos condenados a galés e a pena simples, a partir da portaria de 27 de março de 1829. Era fornecido aos presos, de acordo com a necessidade, o alimento e vestes limpas. Contudo, antes da atuação do hospital, a cadeia enfrentava dificuldades extremas para sustentar seus confinados.

Numa palavra, faziam parte da vida dos presos da Cadeia de Vila Boa penas extremamente severas e privação de coisas básicas do dia a dia. Os direitos dos presos eram diminutos e seus deveres severos. A punição constante, direta ou indireta, associada a falta de estrutura era o que enfrentava a cadeia de Vila Boa, bem como, as demais cadeias da Província de Goiás no século XIX.

\section{Considerações Finais}

A punição no Império do Brasil durante o século XIX e, por consequência, na província de Goiás era viciada e frágil. A mesma não atendia com formas adequadas e justas a sociedade da época, uma vez que exercia punições severas e desproporcionais aos crimes cometidos.

0 perfil dos condenados deste período era formado por negro-escravos, indígena e uma pequena porcentagem de brancos. Assim sendo, restou evidente para quem a justiça imperial era severa já que para os ricos não havia punições com encarceramento, pois estes comprometiam a justiça ao indicar seus serventuários. Além disso, verifica-se que os crimes cometidos em Goiás durante o século XIX, eram em sua maioria crimes contra pessoa, como por exemplo homicídios, ferimentos, roubos e furtos. Nos surpreende a inexistência de crimes públicos, como estelionato e corrupção, o que nos levou a concluir que os havia, mas certamente, havia também, certa negligência por parte das autoridades em punir este tipo de crime.

A cadeia de Vila Boa nos deu uma noção do formato das instalações de cadeias utilizadas no Império do Brasil. Suas características impressionam e demostram as formas de punição que seus reclusos aguardavam. A insalubridade e fragilidade dificultava a efetivação da justiça goiana, além disso proporcionava o horror aos seus inquilinos com a falta de lugar adequado. As penas desproporcionais e severas foram características de uma justiça fraca e ineficaz. As fugas eram constantes, e, em sua maioria, auxiliada por desconhecidos que forçavam as grades da sala forte até que cedessem. A capacidade de vigilância era diminuta devido a falta de contingente da guarda província. No interior das cadeias se destacou a figura do carcereiro que cuidava e vigiava os presos. Compreendemos que esta não era uma profissão atrativa a população goiana que a considerava perigosa. Somados, estes fatores contribuíam para a impunidade e a expansão da criminalidade na província de Goiás.

Compreendemos que a forma de vida da população goiana novecentista era inusitada e possuía características peculiares. Concluímos que, entre 1830-1890, as formas de punição adotadas pela justiça goiana foram as penas de privação de liberdade, contudo violentas e desequilibradas.

\section{Referências}

Acervo Digital do Museu Das Bandeiras. 
Avisos e Ofícios dirigidos à Presidência, pct. 01, Ano 1840, Cx. 30. Doc. Avulsa - Museu das Bandeiras e Arquivo Histórico Estadual de Goiás.

Coralina, C. (2006). Estórias da casa velha da ponte. 13. ed. São Paulo: Global.

Freitas, L. C. B. F. de. (2014). 140 anos de História. Revista Comemorativa do TJGO, Goiânia, 111-26.

Jornal "Goyaz", 26/12/1885, ano I, no 14, p. 1, Hemeroteca Digital Brasileira, e acervo digital do Museu das Bandeiras, transcrito por Milena Bastos Tavares.

Nascimento, W. M. do. (n.d.) Para Onde Pende a Balança: Aplicação da Justiça em Goiás 1830-1890.

Palacin, L. e Morais, M. A. S.(1981) História de Goiás. ed. 4a

Registro dos ofícios, representações e informes, 1824/1828, fl. 70v-72 pct. Tribunal da Relação, Correspondências a Ministério da Justiça Arquivo Real Fazenda, Museu das Bandeiras, Transcrição: Milena Bastos Tavares, historiadora e arquivista.

Relatório apresentado a 15/05/1858 (pp. 14-18) pelo Ministro Francisco Diogo Pereira de Vasconcelos. Ministério da Justiça: Relatórios, pct. 483, Fundo Brasil Império, (Museu das Bandeiras).

Relatório oficial do Ex. Presidente da Província de Goyaz ano de 1856, o Exmo. Dr. Antônio Augusto Pereira da Cunha, referente ao estado de conservação da casa de prisão de Jaraguá. Acervo Digital do Museu Das Bandeiras.

Secretaria da Polícia em Goyaz 18 de maio de 1872. Secretário: Francelino Fenelon de Loyola. (Acervo Digital do Museu das Bandeiras). Transcrição do Mappa Oficial dos carcereiros da Província de Goyaz.

Veiga, M. A. (n.d.). Prospecto da Casa da Câmara e Cadeia de 1751. Museu das Bandeiras, Arquivo Histórico da Cidade de Goiás. 